\title{
The Effects of Authentic and Interactive Video Tasks on Students' Extra Listening Practices
}

\section{Özgün ve Etkileşimli Video Alıştırmalarının Öğrencilerin Dinleme Uygulamaları Üzerindeki Etkileri}

Neslihan KAYNAR*
OIgun SADIK ${ }^{* *}$

Received: 05 December 2020

Research Article

Accepted: 14 April 2021

ABSTRACT: The primary goal of this study is to examine the effects of authentic and interactive video tasks on English as a Foreign Language (EFL) learners' listening practices, perceptions (interest and enjoyment level) regarding using multimedia learning in improving their listening skills. The study involved students from the preparatory school of a university in Turkey. A pre-test and a post-test were given to the students to analyze the effects of authentic and interactive video tasks. The students were asked to reflect on their authentic and interactive video task experience. After the implementation, a questionnaire and interviews were applied to understand the students' overall perceptions regarding the multimedia learning experience. The results of the study show that authentic and interactive video tasks created a positive effect on students' listening practices and influenced their perceptions (interest and enjoyment level) positively. The study results show that the participants found watching these videos out of the classroom appealing and helpful in improving their listening skills.

Keywords: Interactive videos, multimedia, listening skills.

ÖZ: Bu çalışmanın temel amacı, özgün ve etkileşimli video alıştırmalarının üniversite hazırlık programındaki öğrencilerin dinleme uygulamaları ve algıları üzerindeki etkilerini çoklu ortam öğrenimi ve özgünlük açısından incelemektir. Çalışma Türkiye'deki bir üniversitenin hazırlık okulunda öğrenim gören öğrencileri kapsamaktadır. Bu video alıştırmalarının etkilerini araştırmak için öğrencilere ön-test ve son-test uygulanmışır. Bu videolar, araştırmacı tarafından yedi hafta boyunca öğrencilere alıştırma olarak verilmiştir ve her video sonunda öğrencilerden özgün ve etkileşimli video deneyimleri ile ilgili görüşlerini belirtmeleri istenmiştir. Uygulamadan sonra, Çoklu Ortam Teorisi 1şığında uyarlanmış, öğrencilerin ilgi seviyelerini ölçmek için bir anket uygulanmıştır. Nitel verilerin toplanması için öğrenciler ile yarı yapılandırılmış görüşmeler yapılmıştır. Çalışmanın sonuçları, Çoklu Ortam Kuramı 1şı̆̆ında hazırlanan ve belirli öğrenme ilkeleri ile desteklenen özgün etkileşimli video alıştırmalarının, öğrencilerin dinleme uygulamaları üzerinde olumlu bir etki yarattığını göstermektedir. Çalışma sonuçları aynı zamanda ders temalarıyla uyumlu videolar izlemenin öğrencilerin görüşlerini olumlu bir şekilde etkilediğini göstermektedir. Öğrencilerin çoğu, bu videoları ilgi çekici ve yararlı bulduklarını ifade etmişlerdir.

Anahtar kelimeler: Etkileşimli videolar, çoklu ortam, dinleme becerileri.

\footnotetext{
* Corresponding Author: Lecturer, İstanbul University-Cerrahpaşa, İstanbul, Turkey, neslihan.kaynar@iuc.edu.tr, https://orcid.org/0000-0002-7535-428X

** Dr., İnönü University, Malatya, Turkey, olgun.sadik@inonu.edu.tr, https://orcid.org/0000-0002-8852-8189
}

Citation Information

Kaynar, N., \& Sadik, O. (2021). The effects of authentic and interactive video tasks on students' extra listening practices. Kuramsal Ë̆itimbilim Dergisi [Journal of Theoretical Educational Science], 14(3), 291-307. 
Educational technology includes many beneficial tools and resources such as electronic books (Embong et al., 2014), videos, artificial intelligence, augmented and virtual reality applications (Gonzalez, 2017), and so on. With their visual, auditory and interactivity features, videos are among the most popular technology tools in language education. Using videos in language classes is an emerging research topic with interactivity features embedded in videos because ordinary video platforms may not provide learners to get involved in the content of the video (Agarwala et al., 2012). Authentic and interactive videos have been accepted as a valuable resource for language learning because they offer communicative contexts in which learners may feel reality and enhance communication skills (Rammal, 2005; Stempleski \& Arcario, 1992; Stigler et al., 2015). Moreover, according to Kilickaya and Krajka (2010), those multimedia resources provide language learning environments by increasing students' autonomy level and motivation with various learning strategies such as activating students' visual and auditory senses and creating a more entertaining and promoting language learning environment (Kayaoğlu et al., 2011).

Throughout education history, teachers have been inclined to use traditional ways of teaching. This approach needs just the existence of students and teachers in a classroom. However, in today's world, digital technology creates an intense influence on education and how it should be applied regarding future generation's expectations (Salavati, 2013). Film and videos have been used as influential classroom instruction components since 1950 (Marchionini, 2003). Mathew and Alidmat (2013) highlighted that video materials play a positive role in understanding lessons by learners. In this sense, this study explores the effects of authentic and interactive videos on students' listening practices and perceptions in terms of mainly multimedia learning, authenticity and interactivity.

\section{Videos in Language Learning}

Videos are the functional materials that motivate students to increase their academic success if used appropriately according to the instruction process's goals (Thorpe, 2008). With the drastic improvement of technology, videos are widely used in education as they enhance teaching activities (Clark, 2013). Heinich et al. (2002) explained the roles of videos in education as follows:

(a) videos present a concrete referent for ideas;

(b) they draw students' attention by activating emotions;

(c) they make the challenging issues more understandable for learners by simplifying information;

(d) they give opportunities to be understood spoken and written verbal information through visuals (p. 112).

Furthermore, White et al. (2000) indicate that videos are beneficial for students as they help students comprehend complex concepts that are hard to define verbally. In addition, videos are valuable learning materials for learners because they help them enhance themselves in many ways. For example, they contribute to students' learning experiences by increasing their motivational level and enabling them to develop their creative thinking skills (Harmer, 2007). In another research, the role of digital videos in language acquisition was investigated through seven hypotheses and the researcher 
stated that digital videos played a significant role in the process of creating a friendly learning environment (Tschirner, 2001).

\section{Multimedia and Language Learning}

Multimedia Learning firstly has been explained by Mayer (2009) and it has been directly grounded on the principle that states "people can learn more deeply from words and pictures than from words alone" (p. 47). Therefore, messages delivered by the teacher for instructional purposes should be designed according to the way our mind works and also, they should be congruent with the way we learn (Mayer, 2009). Through the developments of multimedia learning, studies have been inclined to search for the effects of multimedia tools on learning and it has been reported in different studies that video materials including both audio and visuals support second language learning. (Silverman, 2013). For instance, Ni (2017) conducted a study with university students to examine the effects of English listening teaching assisted by computer multimedia. The researcher used questionnaires to learn students' opinions about the use of multimedia in improving listening comprehension skills. The researcher found out that the vision feature in the videos assisted students to understand the context better. Moreover, the students found the presentation of information coming from textbooks boring when it was compared to multimedia learning. They addressed that the video materials used in the research were more interesting than traditional materials, which provided more active language learning opportunities to the students.

On the other hand, the researcher $(\mathrm{Ni}, 2017)$ pointed out that video materials were not suitable for some students who had weak self-control ability, as their attention was split. Studies carried out in multimedia contexts have generally used short videos (Markham \& Peter, 2003; Montero Perez et al., 2014) or videos designed for language learning overall (Chung, 1999). However, research efforts have been going on to figure out the ways to improve language learning through interactive videos. Although interactive videos have been in use for a long time, they have not received much interest in instructional settings (Clothier, 2013). According to Mayer (2000), multimedia design principles and the visual items are used for decorative purposes by educators, not for instructional purposes. Moreover, the number of research focusing on the implications of multimedia learning design principles is not enough in the educational video context, although it has been proved that applying them is beneficial for students' learning process (Mayer et al., 1999).

To support multimedia instruction, the videos used in this research were chosen to provide authentic and interactive materials for students to use as authentic videos have many advantages for students, such as serving rich cultural content, presenting real language, and meeting learners' needs (Richards, 2001). In this context, regarding Multimedia Learning, authentic and interactive video tasks may offer opportunities for students to practice their listening skills and also motivate them to listen to authentic resources to internalize the language learning process within the framework. This study describes how authentic and interactive video tasks grounded by Multimedia Learning Theory affect EFL students' listening practices, perceptions, and intentions. The study may also present practical research findings based on the integration of authentic and interactive video tasks to English Language teachers that employ the video in their classrooms successfully. The study addresses the following research questions: 
1. Do authentic and interactive video tasks have any effect on students' extra listening practices in English?

2. How students view the use of authentic and interactive video tasks for extra listening practices in English?

\section{Method}

\section{Research Design}

In this study, the researcher used mixed method research (MMR) design which means "collecting, analyzing, and interpreting both qualitative and quantitative data about the main facts in a single study" (Creswell \& Clark, 2007). In order to answer the research questions, the researcher did not use only one source of data collection because using one source of data resource may not be helpful to obtain reliable and valid results. Lincoln et al. (2011) stated that the use of mixed method strategies can considerably increase the research's understandability. In this research, the researcher studied with a single class. Within the scope of this research, the role of authentic and interactive video tasks and their effects on students' listening practices and perceptions (beliefs and intentions) were investigated.

\section{Participants and Setting}

The study sample consisted of 15 students (eight male-seven female) who study at the English preparatory school of a university in İstanbul, Turkey. Students' ages ranged from 18 to 23. Five of them were international students from predominantly Arab countries such as Qatar, Saudi Arabia and Morocco. The rest of the class consisted of Turkish students. The study took place in the third module of the four-module English program in the university's preparatory year. Students' proficiency level in English is B1-Intermediate. The proficiency level was identified by a reliable and valid placement test conducted by the Testing \& Assessment Unit of the University. However, to ensure the study requirements regarding reliability and validity, a standardized Cambridge PET listening test was conducted again as a pre-test. Based on the participants' exam scores (including placement test and pre-test) before the implementation, it was concluded that both Turkish and Arab students had some difficulties in listening.

The school had a population including more than 750 students. The preparatory school had a modular system consisting of four language levels (1. Elementary 2. PreIntermediate 3. Intermediate 4. Upper-Intermediate). When the students enrolled in the preparatory program, they had a placement test including four main skills in English: listening, reading, writing and speaking. After the placement test, they were randomly assigned to their classes regarding their levels in English. The students whose levels were above B1 level took the proficiency test to be eligible to meet the preparatory school requirements and continued their education in their departments. These placement and proficiency tests were prepared and conducted by the Testing \& Assessment Unit of the school. Three professional subject matter experts managed all of the exam processes in this unit. The videos prepared by the researcher were not used during the lessons because of the reasons which were related to school regulations such as pacing plan or curriculum that are supposed to be followed. Therefore, they were 
assigned to students to work on their own to practice their listening skills and learn their opinions on the use of authentic and interactive videos.

\section{Procedures}

The study was implemented for nine weeks in total at the same class chosen for this research. Prior to the implementation process, the students were given a short tutorial by the researcher to introduce the online tool (Edpuzzle) that they used during this process. The students explored the tool with the help of the instructor in a 40 minutes-class hour and did not experience any technical problems while using the web tool. Before the implementation process, students' listening skills were tested with a standardized Cambridge PET test consisting of 12 questions as well as the placement test conducted at the beginning of the module. After conducting the pre-test, the authentic-interactive videos were prepared aligned with seven units of the course-book used in face-to-face classes. The students were sent weekly authentic and interactive videos prepared by the researcher on the web tool. The students could view all of the videos on their own Edpuzzle accounts. In the fourth and ninth week, no videos were sent to the students as they were the exam weeks. The videos were taken by the Edpuzzle database, which was open-source, including many authentic videos. The videos were adapted through different types of questions such as true/false, multiplechoice or open-ended were selected by the researcher to make them interactive. The questions embedded within the video were prepared regarding different listening skills, such as guessing the word's meaning or listening for specific details that might help the learners during the course. The students watched the authentic interactive videos, answered the embedded questions and commented about their experiences. The researcher followed the students' process and their reactions to these authentic and interactive video tasks every week. After the students watched the last video, they were asked to take the post-test. A Likert-scale perceptions questionnaire combining different themes of the study (multimedia learning, authenticity and interest/enjoyment level) was implemented. Following the questionnaire, twelve interviews based on the students' opinions were conducted by the researcher.

\section{Data Collection}

Firstly, quantitative data was collected to interpret students' listening performances before the implementation process. In the following phase, qualitative data was collected to answer the second research question successfully. The students' performances on these videos were evaluated weekly via the online platform used to provide the videos. In the next phase, the students' opinions on the use of authentic and interactive videos for extra listening practices were collected through the open-ended questions asked at the end of each video task. Finally, to obtain students' perceptions about the use of these videos, semi-structured interviews consisting of seven questions were conducted with twelve participants.

\section{Instruments}

\section{Pretest \& Postest}

The pre-test aimed to measure the participants' listening competency in EFL before implementing authentic and interactive video tasks in the course and to ensure 
the test-retest reliability in the research. The test taken from the Cambridge PETListening part consisted of two sections with twelve questions and students were expected to complete the test in 20 minutes. Also, this test was examined and validated by two English instructors from the university setting. The same items and structures were used in the post-test test to explore whether participants' listening performances changed after the implementation process. The answers of the tests and students' performances were not announced in the process.

\section{Students' Performances \& Grades}

The interactive video platform, Edpuzzle was used in this research to provide authentic and interactive video tasks to students. The authentic videos assigned to the students were taken from open sources such as Youtube, Khan Academy or National Geographic provided by Edpuzzle database. By using this platform, the teachers may crop the video that they choose, record their voices, add clarifications and embed quizzes along the video to check students' comprehension of the video by changing the authentic video to an interactive video. Additionally, the platform had a grading system to track students' learning performances within seconds easily. Teachers can see the class performance, grade and individual student performance out of 100 points and make comments on each performance to give more personalized feedback to students. Teachers can also learn how much time students spend on the video and how many questions students answered correctly. In this sense, the researcher benefited from all features of this platform to learn students' performances on the authentic and interactive videos.

\section{Students' Comments at the End of the Videos}

Using this interactive video platform, teachers may have a chance to give written feedback to their students at the end of each video. Moreover, at the end of each video, students can give written feedback about their opinions or comments. The researcher benefited from this feature of the platform and asked students to write about their experiences on watching authentic interactive videos. After the students explained their opinions at the end of the videos, the researcher graded students' performances on the authentic and interactive videos, gathered and saved the data consisting of students' comments to the question such as "How was your authentic-interactive video experience? How did you feel at the end of this video?" were asked.

\section{Interviews}

The questions used for the interview were prepared by the researcher and a subject matter expert. The students were interviewed separately by the researcher, their responses were voice recorded and the researcher transcribed students' responses verbatim on a laptop computer. Each item in the semi-structured interview questions focuses on three main sections of the research questions: (1) Multimedia Learning Theory (2) Authenticity and (3) Perceptions. The researcher directed the questions in the interview according to the participants' answers. In this sense, below were the examples of the primary questions included in the interview:

1) What do you think about your experience of watching the authentic interactive videos? 
2) How do you think watching interactive videos influenced your listening skills?

3) Were there any motivational factors of watching interactive videos for our listening class? Do you think that they motivated you or not? Please explain.

\section{Activities that Students Did during the Tasks}

According to Brown (2001), listening strategies should be taught to students who are in the process of acquiring a new language because these strategies are helpful for them to understand the listening text better. The students who participated in this study were taught these strategies since the beginning of the academic year and during the class hours to improve their listening skills. Students were asked questions requiring different listening strategies in the authentic and interactive videos. The researcher used listening comprehension questions to measure student's understanding. If comprehension questions are asked properly, they improve students' higher-order thinking skills and critical thinking skills. (Egbert et al., 2009).

Listening for specific details. This strategy requires students to focus on details and pay closer attention to the listening text. Students were asked questions to find the important details in the videos, such as dates, people or places. For example, a multiplechoice question was asked in the first video related to Thai traditions: How often do rings need to be refitted?

Listening to make inferences. Inference questions were used in the videos that students watch the authentic-interactive videos and can make inference to find out what a concept literally means in the related context. For instance, students were asked to infer the meaning of the target vocabulary in the video about Thailand traditions: What does "fled to" (past form of flee) mean?

Using nonverbal cues. As the videos were used in this research, the students were exposed to non-verbal cues and they could understand the context of the video better with the help of visuals, gestures and facial expressions of people in the videos. To give an example, "Do you think that these women feel happy with the rings around their necks? Why?"

\section{Reliability and Validity}

Reliability that focuses on consistency, dependability and replicability of the findings of the data collected in a study is one of the most important requirements of research (Nunan, 1999, p. 14). Lincoln and Guba (1985) and Merriam (1998) stated that reliability can be guaranteed through different techniques such as an investigator's position, triangulation and audit trial. In this research context, the investigator was an insider to interpret the data collected. Different validation strategies were used in this research to validate the findings (Creswell \& Clark, 2007; Patton, 2002). In order to validate the data, the researcher explained all procedures during the implementation explicitly. First of all, research questions were explained to clarify the important aspects of the research. The questionnaire, the students' comments at the end of each video experience, and lastly, the interviews conducted with the participants served as strategies to validate the findings with multiple data collection instruments.

Furthermore, the audit trail technique was used in this research to follow research stages regularly. Throughout the research process, the researcher took notes weekly to record as much information as possible to understand and interpret the 
findings. To obtain smooth data, interpret and analyze it in a detailed way, the researcher took notes during the research that may help her understand the authentic and interactive video tasks. The questionnaire used in the research was also piloted to measure the understandability of the questionnaire items for the students as the questionnaire was modified to make it more suitable for the research sample. The alpha coefficient value was measured as .85 . To ensure the reliability of the items, a single similar group of B1 students took part as a pilot group. When it comes to the qualitative phase of the study, questions for the semi-structured interviews were prepared by the researcher with the help of a subject matter expert. Although the researcher did not have any bias or thread for students' responses, the participants were rated only by the researcher.

\section{Piloting the Survey}

According to Creswell (2007), a pilot test is used as an instrument by getting feedback from a small number of individuals in order to test the understandability of the items. For this reason, the researcher benefited from a pilot test to grant the easiness and understanding of the survey items. For this study, when the alpha coefficient was measured, it was found as .85. The survey used within the scope of the research was piloted with 16 participants. They were B1 level students studying in a different class and they were not included in the authentic and interactive video watching process. The pilot survey was applied in a 40-minutes class hour. The researcher took note the time taken to complete the survey. At the end of the survey, the pilot participants were asked to give feedback and also asked whether there were some wordy or unclear items in the survey. The majority of the students did not point out any ambiguity related to the questionnaire items. They mentioned that the sentences were given explicitly. Only two students stated that they did not exactly understand the fourth item in the questionnaire. They pointed out that they do not know the meaning of a word (conversational) in the statement. For this reason, the researcher gave a synonym of the word in the parenthes is and also provided an example with the statement to make it more meaningful for the research group. The other pilot participants stated that the survey is convenient to use and clear enough to understand each item.

\section{Data Analysis Procedure}

The data collected from the participants were examined and provided through different themes in this research. The data analysis process took approximately three weeks after the data was collected. In order to obtain a more detailed perception of the students' authentic and interactive video experiences, as well as the impact of these perceptions on test scores, two kinds of qualitative data were aimed to collect and analyze.

The first one is the students' comments at the end of each video and the second is the interview data. First of all, the students' comments at the end of each video were analyzed thematically. The analysis of students' comments was compared with the results of the quantitative phase of this study. Following the implementation process, the students were interviewed individually, and their answers were recorded. Then, these responses were typed on a laptop computer. Generally, all the interviews lasted from four to six minutes. After conducting the interviews, the students' responses were 
coded with the statements on an electronic system by the researcher. The themes in this study were defined uncomplicatedly because students' answers to the interview questions were similar to each other. After examining the codes, the data were divided into different categories addressing commonality. Igo et al. (2005) followed the same procedure while identifying categories from students' interviews in a similar way. The interview data explained the opinions of twelve students and five themes emerged: 1) the students' general experiences on authentic and interactive video tasks 2) the students' opinions about the effect of authentic and interactive video tasks on listening practices 3) students' opinions about multimedia learning 4) students' opinions about authenticity.

\section{Ethical Procedures}

All procedures performed in this study involving human participants were in accordance with the ethical standards of the institutional research committee. Before the research started, the researcher applied the institutional ethics committee for ethical approval. The ethical committee approval date is May 3, 2019 and the number of the approval document is 96136591-050.06.04-E.10191. The students who agreed to participate in the study were given consent forms. In order to keep the confidentiality of the students, pseudonyms were assigned to all participants after the data collection.

\section{Results}

\section{Pretest \& Post-test Results}

According to the descriptive analysis, it has been found out that there was a difference between the pre-test and post-test scores of most of the students who participated in this study after the implementation of authentic and interactive video tasks while four of them did not show a significant improvement in those tests. The pretest and post-test scores were analyzed through Wilcoxon Signed Rank Test. According to test results, there was found a significant difference after the implementation of authentic and interactive videos. The significance value was found to be $.20(p<.001)$. (two-tailed).

\section{Students' Performances on the Tasks}

The students' video performances were graded throughout the implementation process and data from the platform was analyzed accordingly. Students' performances in each video were evaluated and compared one by one to find out whether their individual experiences on these video tasks improved or not. As a result of the analysis process, ten of 15 students increased their scores periodically. However, the reports also showed that authentic and interactive video tasks did not make a big difference for five students on the weekly process.

\section{Findings of the Questionnaire}

The questionnaire used as an instrument in this research consisted of 13 statements focusing on research question areas: Multimedia Learning, authenticity and perceptions (interest and enjoyment level). In this sense, the data coming from this questionnaire were categorized into three different sections: 1) multimedia 2) 
authenticity 3) students' perceptions about the use of authentic and interactive video tasks.

The students' responses to the related statements of the questionnaire were analyzed and it was found out that 14 of the 15 students participated in this research thought that they learn better when the words and pictures are presented together, which is the fundamental of Multimedia Learning (Mayer, 2009). When students' answers to the statement: "Watching short authentic-interactive videos helped me better understand the content of the course" were analyzed, it was found that 13 of students strongly agreed and one of them agreed with the idea about the contribution of watching these videos to the understanding of course topics while only one student disagreed with this statement.

The other statement was about the voice principle of Multimedia proposing that human voice is more helpful than machine voice according to tests done: "I learned better with a human voice than a machine voice". Students were provided all videos that included human voice regarding the voice principle of Multimedia Learning. Ten students agreed that human voice was more effective for students' learning rather than the machine voice. On the other hand, five of the students stated that they neither agreed nor disagreed with this statement.

All of the videos used in this research were authentic materials produced by native speakers of English. In order to find how authenticity affected students' ideas, four statements were given in the questionnaire. When the responses were analyzed, nine students strongly agreed that the videos were relevant to real life. Eight of them strongly agreed that use of real language in the videos has a positive effect on the improvement of the listening skills and four of them also agreed with this positive effect. However, three of the students chose "neither agree or disagree". Additionally, this research aimed to explore whether use of real-life videos increased students' interest and enjoyment while listening. Eight of the students strongly agreed that these videos motivated them more to use language, while three of them neither agreed nor disagreed with this statement. When it comes to the videos providing information from the current world, ten students strongly agreed that they learned about the current world via these videos. Two students agreed with this idea. Three students said "neither agree nor disagree" as they were indecisive in this view.

\section{Students' Perceptions of the Videos}

To investigate students' perceptions of the effect of these video tasks, the items focusing on interest and enjoyment level were taken from Intrinsic Motivation Inventory (IMI) and adapted according to the content of this research. Students were asked whether they found them enjoyable or not. When they watched these videos out of the classroom, nine of them stated that they strongly agreed that these video tasks were motivating for them. Three of them agreed, while two of them said: "neither agree nor disagree". No students chose "disagree or strongly disagree" items. In this sense, it was reported that most students had positive perceptions about the use of these tasks. Secondly, students were asked whether watching authentic-interactive videos made their learning more enjoyable for them or not. While ten of them strongly agreed, three of them agreed that these videos created pleasurable learning for them. On the other hand, two students disagreed with this statement. Lastly, to learn students' intentions about 
watching authentic and interactive videos in the future, "I am willing to watch interactive videos again." statement was provided for them. Most of the students reported that they would like to watch these videos again in the future. Only one student was not willing to watch interactive videos.

\section{Interview Findings}

For the qualitative aspect of the research, students were asked their opinions via semi-structured interviews at the end of the nine-week video task process. It was aimed to investigate students' experiences on these authentic and interactive video tasks, their opinions about the effect of multimedia and authenticity factors on their listening skills and perceptions. For this reason, the findings were examined and divided into four groups. The themes obtained from the interviews are provided below.

\section{Students' General Experiences on the Videos}

The majority of the students stated their positive perceptions on the use of authentic-interactive video tasks. After examining students' views, the themes were categorized accordingly. When the students were asked about their general experiences on the use of these video materials, eight of twelve students reported that they learned different topics such as culture or global issues while watching authentic and interactive videos. Some of the students pointed out the easiness and practicality features of the videos used in the research. Three of the students stated that the videos served as useful materials during the implementation process. One of the students explained his ideas as follows; "It is really easy to use. When you sent them to us, I could open and watch it easily" (Participant 3, March 26, 2019).

\section{Students' Perceptions of the Effect of the Videos on Enjoyment and Interest Level}

Although the items adapted from Intrinsic Motivation Inventory (IMI) were provided in the questionnaire to obtain the students' results, semi-structured interview was also used to ensure the data. Students were asked questions about the effect of these videos on their interest and enjoyment level. Students responded to the question: "Were there any motivational factors of watching interactive videos for our listening class? Did they motivate you? Do you think that watching authentic and interactive videos is enjoyable? Please explain." Except for one student, most students stated that the videos they watched during the process motivated them to listen and watch more.

Moreover, some students declared that they feel better when they watch the videos because they find them enjoyable and an effective way to practice English. One of the students expressed her opinions as follows: "Of course. They motivated me to watch more and improve my listening skills. I heard native speakers, learned general cultural information and I believed myself, I can be better" (Participant 2, March 26, 2019). On the other hand, one student considers that authentic-interactive videos did not increase his motivation in this process. He said: "It does not have a big effect on my motivation." (Participant 6, March 26, 2019) Also, one student thinks that his motivation level changed according to the video he watched. The student expressed his opinions below; "It depends on the video. Not all of them were motivating, but some of them motivated me to practice more." (Participant 3, March 26, 2019). 


\section{Students' Opinions about the Effects of Video Tasks on Listening Practices}

The students commented on the effect of these videos on their listening practices. The students pointed out that these videos affected their listening practices positively in different scopes such as vocabulary learning, pronunciation and interactivity. The interview data collected from the students also show that that the students regard authentic-interactive videos as an opportunity to improve their listening skills out of the classroom. In this sense, nine of twelve students stated that these materials help them practice their listening skills effectively. Four students explained their comments about the effect of these videos on listening skills and they pointed out that they learned how to pronounce some vocabulary items through the videos. One of the students expressed his ideas:

We have a listening exam in this module. They are mid-term and final exams. During this module, we studied these videos and they helped me a lot. I learned how to pronounce the words. For example, if I do not remember how to pronounce a word, I try to remember the video. Then I remember its pronunciation (Participant 6, March 26, 2019).

One of the students also commented on the questions asked in each video. She pointed out the effect of different question types such as multiple-choice, open-ended or true/false on her listening skills. She said: "I answered the questions about these people. Sometimes I choose the answer or write the answers and it improves my listening skills different question types." (Participant 11, March 26, 2019). On the other hand, only two students stated that their first video experiences were challenging for them. One of them expressed his ideas as follows;

It was difficult. Really. When I watched it for the first time, it was really hard for me to understand the video. But later, it was better than the first one. And when I watched the last video, I noticed that I can watch videos and understand them easily (Participant 10, March 26, 2019).

\section{Students' Opinions about Multimedia Learning}

The students were asked whether they prefer watching authentic-interactive videos or only reading/ listening materials. Except for only one student, all of the students preferred video materials indicating the multimedia effect. The students pointed out that videos are more effective tools for learning as they have both visuals and narration at the same time. One of the students expressed their opinions as follows;

Actually, for me, I prefer to watch and listen to videos because it is better than only reading or listening. I love watching listening videos. I understand better when I watch rather than only reading. You do not see photos or visuals when you are reading. I can understand better by watching the video (Participant 1, March 26, 2019).

The other category was the students' opinions about pre-training before watching the videos. When the students were asked how these pre-training sessions in the class hours affected their learning, all of them responded positively to this question. The students also stated that they learn new concepts and information through the video but pre-training sessions make learning more effective. One of the students also indicated that watching videos is a more personalized activity when it is compared to ordinary lessons. He expressed his ideas as follows;

Actually, you are repeating the same topic in an effective way through the videos. So, you cannot forget easily because you read and cover something in the class. Then you practice it but not as a lesson, as a normal life activity. I think it is more personalized, individual and special (Participant 2, March 26, 2019). 


\section{Students' Opinions about Authenticity}

Authenticity is one of the focus points of this research as the research aims to find out how authentic videos create an effect on students. At the end of the interview, most of the students explained that they like watching authentic videos because they see them as materials from real life. One of the students pointed out that he enjoys watching these videos out of class as an extra activity. He said: "I think watching real video out of class is good because we do not have much time in the class and we can practice through these videos out of class more" (Participant 1, March 26, 2019).

In conclusion, most of the students who participated in this research stated their positive comments on using authentic and interactive videos out of the classroom. When the data was analyzed, it can be said that almost most of the students enjoyed watching authentic and interactive videos. Furthermore, the students found these materials an opportunity to improve their listening skills in terms of comprehension, pronunciation, learning new vocabulary, etc. When it comes to the perceptions of the students, the interviews conducted with twelve students showed that they found it useful and enjoyable to watch authentic and interactive videos not only to improve their listening skills but also to learn new/cultural information. The students also mentioned the effect of multimedia in the videos implicitly. When they were asked the question "Would you prefer only reading the book, listening to the audio, or watching interactive videos to learn or practice?", Fourteen of them preferred watching the authentic and interactive video by indicating the visual and auditory input provided at the same time.

\section{Discussion and Conclusion}

The first research question of the study aims to investigate the effects of authentic and interactive videos on students listening practices. According to the pre-test and post-test results, students got higher scores in the post-tests after watching the authentic and interactive videos. Although most students' performances increased gradually in the weekly videos, fluctuations also were observed in some students' performances. However, when the mean scores for each participant were analyzed, these fluctuations did not have a negative impact on students' achievements. These results were also supported by students' comments asked at the end of each video and through a questionnaire including different research areas. Most of the students stated their positive opinions on the use of authentic and interactive videos out of class. They reported that these videos are helpful for their listening practices. Students' grades and also comments were compatible with each other. The students consider that watching authentic and interactive videos is an opportunity for them to practice the topics they have learned in the class hours and learn new information about the world or different cultures. When it comes to interest and enjoyment level, the students stated that authentic and interactive videos motivated them to listen more as they enjoyed. Most of the students explained that they would like to watch these videos and practice through them again. It can be concluded that multimedia learning has a positive effect on students' video experiences.

The findings of the study are also compatible with the previous studies in the field. In this context, Ni (2017) carried out a study focusing on the effects of multimedia tools in listening comprehension. To find out students' perceptions of the use of multimedia materials, the researcher used a questionnaire as a research instrument and 
multimedia features such as visuals and audio were found appealing by the students. Similarly, in this research, the students found the video materials more interesting and enjoyable than the books or only listening materials. With the help of Multimedia, learners take place in a learning environment as active participants (Neo \& Neo, 2001).

Similarly, most of the students in this study addressed that they learn better when exposed to visual and audio input. They stated that they improved their listening skills in comprehension, learning new vocabulary, pronunciation, etc. However, using videos regarding multimedia learning cannot be the only reason why the students performed better in post-test scores and video grades. Authentic tasks have been used in instruction settings by colleges and universities around the world to lead learning. (Herrington et al., 2010). Ten of twelve students addressed the authentic and interactive videos as real-life examples. Overall, these findings are in accordance with the findings reported by Weyers (1999). The researcher investigated the effects of authentic videos on students' listening comprehension and communicative competence with Spanish university students. The experimental group was asked to watch 13 episodes of a Spanish drama. The research results show that the experimental group performed better in listening comprehension and communicative competence than the control group. The students in this study also enjoyed interacting with these videos as authentic tasks promote self-directed and independent learning, which is a significant element for technology-based learning. (Herrington et al., 2003).

In conclusion, this research aimed to explore the effects of authentic and interactive video tasks on students' listening practices and perceptions regarding multimedia learning and authenticity factor. The research shows that authentic and interactive video tasks were useful and helpful for the students as they created a positive effect on their extra listening practices and perceptions as well as presenting an enjoyable learning activity. Although the results of the study indicate an improvement in students' video grades recorded via the platform and post-tests, their performances could be influenced by other factors. For example, the students' interests, characters, learning backgrounds, or study habits are different, affecting the study results to a great extent. Moreover, technological readiness and the attitude and acceptance of users are important factors that need to be focused on by researching this field (Tick, 2006). Therefore, instructors play a role as facilitators. They need to design suitable learning environments and video materials considering the students' needs to motivate them in this process (Hadijah, 2016).

\section{Statement of Responsibility}

Neslihan Kaynar; research design, analysis, methodology, data collection, resources, discussion, conclusion, writing-original draft, writing - review \& editing. Olgun Sad1k; methodology, writing -original draft, writing - review \& editing, resources, discussion, conclusion, supervision.

\section{Conflicts of Interest}

There are no conflicts of interest in this study. 


\section{References}

Agarwala, M., Hsiao, I. H., Chae, H. S., \& Natriello, G. (2012, July). Vialogues: Videos and dialogues based social learning environment. Proceedings of the 12th International Conference on Advanced Learning Technologies (pp. 629-633). http://dx.doi.org/10.1109/ICALT.2012.127

Brown, H. D. (2001). Teaching by principles: An interactive approach to language pedagogy (2nd ed.). Pearson Education.

Chung, J. M. (1999). The effects of using video texts supported with advance organizers and captions on Chinese college students' listening comprehension: An empirical study. Foreign Language Annals, 32(3), 295-308. http://dx.doi.org/10.1111/j.19449720.1999.tb01342.x

Clark, M. (2013). The use of technology to support vocabulary development of English Language Learners. Education Masters. Retrieved from https://fisherpub.sjfc.edu/cgi/viewcontent.cgi?article=1239\&context=education_ET D_masters

Clothier, P. (2013, October 28). Interactive video: The next big thing in mobile. Learning Solutions Mag. Retrieved from https://learningsolutionsmag.com

Creswell, J. W. (2007). Designing and conducting mixed method research. Sage.

Egbert, J., Huff, L., McNeil, L., Preuss, C., \& Sellen, J. (2009). Pedagogy, process, and classroom context: Integrating teacher voice and experience into research on technology-enhanced language learning. The Modern Language Journal, 93, 754768. http://dx.doi.org/10.1111/j.1540-4781.2009.00971.x

Embong, A. M., Noor, A. M., Rafek, M., Othman, H., \& Khalid, P. Z. M. (2014). What do teachers and pupils say about using e-books in the classrooms? International Journal of Social Science and Humanity, 4(6), 451-457. http://dx.doi.org/10.7763/IJSSH.2014.V4.397

Gonzalez, F., Pizarro, M., Cermeron, R., Li, K., Thorn, J., Hutabarat, W., \& Bermell, P. (2017). Immersive mixed reality for manufacturing training. Frontiers in Robotics and AI, 4(3), 1-8. https://doi.org/10.3389/frobt.2017.00003

Hadijah, S. (2016). Teaching by using video: Ways to make it more meaningful in EFL classrooms. Proceedings of ISELT FBS Universitas Negeri Padang, 4(2), 307-315.

Harmer, J. (2007). The practice of English language teaching (4th ed.). Pearson Education Limited.

Heinich, R., Molenda, M., Russell, J. D., \& Smaldino, S. E. (2002). Instructional media and technologies for learning. (7th ed.). Pearson College Div.

Herrington, J., Oliver, R., \& Reeves, T. C. (2003). Patterns of engagement in authentic online learning environments. Australian Journal of Educational Technology, 19(1), 59-71. http://dx.doi.org/10.14742/ajet.1701

Herrington, J., Reeves, T. C., \& Oliver, R. (2010). A guide to authentic e-learning. London: Routledge. http://dx.doi.org/10.4324/9780203864265

Igo, L. B., Bruning, R. H., \& McCrudden, M. (2005). Exploring differences in students' copy and paste decision-making and processing: A mixed-methods study. Journal of Educational Psychology, 97, 103-116. http://dx.doi.org/10.1037/00220663.97.1.103 
Kayaoğlu, M., Akbaş, R., \& Öztürk, Z. (2011). A small scale experimental study: Using animations to learn vocabulary. Turkish Online Journal of Educational Technology, 10, 24-30.

Kilickaya, F., \& Krajka, J. (2010). Comparative usefulness of online and traditional vocabulary learning. Turkish Online Journal of Educational Technology, 9(2), 5563.

Lincoln, Y. S., \& Guba, E. G. (1985). Naturalistic inquiry. Newbury Park, CA: Sage. http://dx.doi.org/10.1016/0147-1767(85)90062-8

Lincoln, Y. S., Lynham, S. A., \& Guba, E. G. (2011). Paradigmatic controversies, contradictions, and emerging confluences revisited. In N. K. Denzin \& Y. S. Lincoln (Eds.), The sage handbook of qualitative research (4th ed., pp. 97-128). Sage.

Marchionini, G. (2003). Video and learning redux: New capabilities for practical use. Educational Technology, 43(2), 36-41.

Markham, P., \& Peter, L. (2003). The influence of English language and Spanish language captions on foreign language listening/reading comprehension. Journal of Educational Technology Systems, 31(3), 331-341. http://dx.doi.org/10.2190/BHUH-420B-FE23-ALA0

Mathew, N., \& Alidmat, A. (2013). A study on the usefulness of audio-visual aids in EFL classroom: Implications for effective instruction. International Journal of Higher Education, 2(2), 86-91. http://dx.doi.org/10.5430/ijhe.v2n2p86

Mayer, R. E. (2009). Multimedia learning (2nd edition). Cambridge University Press. https://doi.org/10.1017/CBO9780511811678

Mayer, R. E., Moreno, R., Boire, M., \& Vagge, S. (1999). Maximizing constructivist learning from multimedia communications by minimizing cognitive load. Journal of Educational Psychology, 91(4), 638-643. https://doi.org/10.1037/00220663.91.4.638

Merriam, B. (1998). Qualitative research and case study applications in education. Jossey-Bass.

Montero Perez, M., Peters, E., Clarebout, G., \& Desmet, P. (2014). Effects of captioning on video comprehension and incidental vocabulary learning. Language Learning \& Technology, 18(1), 118-141.

Neo, M., \& Neo, T. K. (2001). Innovative teaching: Using multimedia in a problembased learning environment. Educational Technology \& Society, 4(4), 19-31.

Ni, D. (2017). Design and research on English listening teaching assisted by computer multimedia. International Journal of Emerging Technologies in Learning, 12(1), 32-43. http://dx.doi.org/10.3991/ijet.v12i01.6053

Nunan, D. (1999). Research methods in language learning. CUP.

Patton, M. Q. (2002). Qualitative research and evaluation methods. Sage.

Rammal, S. (2005, April 12-13). Using video in the EFL classroom. The CDELT 25th Annual Symposium. 
Richards, J. C. (2001). Postscript: The ideology of TESOL. In Carter, R. \& Nunan, D. (Eds.), The Cambridge guide to teaching English to speakers of other languages (pp. 294). Cambridge University Press.

Salavati, S. (2013). Novel use of mobile and ubiquitous technologies in everyday teaching and learning practices: A complex picture (Doctoral dissertation). Linnaeus University.

Silverman, R. (2013). Investigating video as a means to promote vocabulary for at-risk children. Journal of Contemporary Educational Psychology, 38, 170-179. http://dx.doi.org/10.1016/j.cedpsych.2013.03.001

Stempleski, S., \& Arcario, P. (1992). Video in second language teaching: Using, selecting and producing video for the classroom. TESOL Publications.

Stigler, J., Geller, E., \& Givvin, K. (2015). Zaption: A platform to support teaching and learning about teaching with video. Journal of E-Learning and Knowledge Society. 11(2), 13-25.

Thorpe, R. (2008). Digital technology in classrooms: Video in teaching and learning. NHK Broadcasting Studies, 6, 21-45.

Tick, A. (2006). From computer assisted language learning to computer mediated language learning. In Proceedings of 4th Joint Slovakian-Hungarian Symposium on Applied Machine Intelligence SAMI (pp. 450-459).

Tschirner, E. (2001). Language acquisition in the classroom: The role of digital video. Computer Assisted Language Learning, 14(3-4), 305-319. http://dx.doi.org/10.1076/call.14.3.305.5796

Weyers, J. R. (1999). The effect of authentic video on communicative competence. The modern language journal, 83(3), 339-349. http://dx.doi.org/10.1111/00267902.00026

White, C., Easton, P., \& Anderson, C. (2000). Students' perceived value of video in a multimedia language course. Educational Media International, 37(3), 167-175. http://dx.doi.org/10.1080/09523980050184736

This is an Open Access article distributed under the terms of the Creative CommonsAttributionNonCommercial-ShareAlike 4.0 International (CC BY-NC-SA 4.0). For further information, you can refer to https://creativecommons.org/licenses/by-nc-sa/4.0/ 